\title{
GENOME-ENABLED DISCOVERY OF CARBON SEQUESTRATION GENES IN POPLAR
}

\author{
Final Report \\ June 15, 2004 - June 14, 2007 \\ Sergei Filichkin, Elizabeth Etherington, Julie Grammer, and Steve Strauss
}

February 22, 2007

US Department of Energy grant award no. 4000023558

\author{
Oregon State University
}

Department of Forest Science

321 Richardson Hall

Corvallis, OR 97331 


\section{DISCLAIMER}

This report was prepared as an account of work sponsored by an agency of the United States Government. Neither the United States Government nor any agency thereof, nor any of their employees, makes any warranty, expressed or implied, or assumes any legal liability or responsibility for the accuracy, completeness, or usefulness of any information, apparatus, product, or process disclosed, or represents that its use would not infringe privately owned rights. Reference herein to any specific commercial product, process or service by trade name, trademark, manufacturer, or otherwise does not necessarily constitute or imply its endorsement, recommendation, or favoring by the United States Government or any agency thereof. The views and the opinions of authors expressed herein do not necessarily state or reflect those of the United States Government or any agency thereof. 


\section{TABLE OF CONTENTS}

Executive Summary

Report Detail

Conference Papers/Proceedings and Journal Articles

Table 1
4

5

10

12 


\section{EXECUTIVE SUMMARY}

The goals of the S.H. Strauss laboratory portion of "Genome-enabled discovery of carbon sequestration genes in poplar" are (1) to explore the functions of candidate genes using Populus transformation by inserting genes provided by Oakridge National Laboratory (ORNL) and the University of Florida (UF) into poplar; (2) to expand the poplar transformation toolkit by developing transformation methods for important genotypes; and (3) to allow induced expression, and efficient gene suppression, in roots and other tissues.

As part of the transformation improvement effort, OSU developed transformation protocols for Populus trichocarpa 'Nisqually-1' clone and an early flowering P. alba clone, 6K10. Complete descriptions of the transformation systems were published (Ma et. al. 2004, Meilan et. al 2004). Twenty-one 'Nisqually-1" and 622 6K10 transgenic plants were generated.

To identify root predominant promoters, a set of three promoters were tested for their tissuespecific expression patterns in poplar and in Arabidopsis as a model system. A novel gene, ET304, was identified by analyzing a collection of poplar enhancer trap lines generated at OSU (Filichkin et. al 2006a, 2006b). Other promoters include the $p G g M T 1$ root-predominant promoter from Casuarina glauca and the pAtPIN2 promoter from Arabidopsis root specific PIN2 gene.

OSU tested two induction systems, alcohol- and estrogen-inducible, in multiple poplar transgenics. Ethanol proved to be the more efficient when tested in tissue culture and greenhouse conditions. Two estrogen-inducible systems were evaluated in transgenic Populus, neither of which functioned reliably in tissue culture conditions.

GATEWAY-compatible plant binary vectors were designed to compare the silencing efficiency of homologous (direct) RNAi vs. heterologous (transitive) RNAi inverted repeats. A set of genes was targeted for post transcriptional silencing in the model Arabidopsis system; these include the floral meristem identity gene (APETALA1 or AP1), auxin response factor gene (ETTIN), the gene encoding transcriptional factor of WD40 family (TRANSPARENTTESTAGLABRA1 or TTG1), and the auxin efflux carrier (PIN-FORMED2 or PIN2) gene. More than 220 transgenic lines of the $1^{\text {st }}, 2^{\text {nd }}$ and $3^{\text {rd }}$ generations were analyzed for RNAi suppression phenotypes (Filichkin et. al., manuscript submitted).

A total of 108 constructs were supplied by ORNL, UF and OSU and used to generate over 1,881 PCR verified transgenic Populus and over 300 PCR verified transgenic Arabidopsis events. The Populus transgenics alone required Agrobacterium co-cultivations of 124.406 explants.

KEYWORDS: Populus, Arabidopsis, root promoter, alcohol-inducible gene expression, RNAi, trichome, AT-hook, P. trichocarpa 'Nisqually-1' 


\section{REPORT DETAIL}

The goals of the S.H. Strauss laboratory portion of "Genome-enabled discovery of carbon sequestration genes in poplar" are (1) to explore the functions of candidate genes using Populus transformation by inserting genes provided by Oakridge National Laboratory (ORNL) and the University of Florida (UF) into poplar; (2) to expand the poplar transformation toolkit by developing transformation methods for important genotypes; and (3) to allow induced expression, and efficient gene suppression, in roots and other tissues.

\section{The specific Oregon State University objectives and tasks included:}

2.1. Develop the Populus transformation toolkit

2.1.1. Develop efficient transformation protocols for model Populus clones

2.1.2. Identify root-predominant promoters

2.1.3. Create inducible promoter system for Populus

2.1.4. Construct RNAi vectors for efficient ubiquitous, root-predominant and/or inducible suppression of target genes

2.2. Create a population of transgenics of each candidate gene designed to yield maximum information about gene function

2.2.1. Create invertase transgenics

2.2.2. Create cytokinin response factor and auxin response factor transgenics

2.2.3. Create AUX/IAA transgenics

2.2.4. Create sink strength transgenics

\subsection{Development of the Populus transformation toolkit}

2.1.1. As a part of the transformation improvement effort, OSU developed transformation protocols for Populus trichocarpa 'Nisqually-1', with known genome sequence, and early flowering $P$. alba (6K10) clones.

- A total of 21 'Nisqually-1' transgenic plants were generated. A complete description of transformation system for 'Nisqually-1' was published (C. Ma, S. H. Strauss, and R. Meilan. 2004. Agrobacterium-mediated transformation of the genome-sequenced poplar clone, 'Nisqually-1' (Populus trichocarpa). Plant Molec Biol Reporter., 22, p.1-9). 
- A total of 622 transgenic plants were generated using the early flowering 6K10 clone. The average frequency of the developed $6 \mathrm{~K} 10$ clone transformation system ranged from 2 to $4 \%$. Five major classes of constructs were used for 6K10 transformation:

1. RNAi constructs (a total of 552 transgenic plants);

2. overexpression constructs (70 transgenics);

3. ablation constructs (10 transgenics);

4. promoter - reporter gene constructs (74 transgenics); and

5. dominant negative mutants (79 transgenics).

2.1.2. To identify root predominant promoters a set of three promoters were tested for their tissue-specific expression patterns in poplar and in Arabidopsis as a model system.

By analyzing a collection of poplar enhancer trap lines generated at OSU, we identified a novel gene ET304. This gene is highly active during formation of adventitious and lateral roots and encodes a putative protein with a single predicted AT-hook motif, DNA binding domain, and nuclear localization signal. An isolated ET304 promoter fused to the GUS reporter gene directed strong auxin-inducible expression in meristematic cells of root tips and lateral root primordia, both in poplar and Arabidopsis (Filichkin et al., 2006a). The later raised a possibility that ET304, and other genes from this gene family, may play an important role in initiation, development, and branching of lateral roots.

The lateral root-specific expression pattern of pET304 was confirmed by the analysis of $\mathrm{T}_{1}, \mathrm{~T}_{2}$ and $\mathrm{T}_{3}$ generations of transgenic Arabidopsis. We searched the poplar genome for genes that share sequence similarity with ET304. In preliminary studies, using poplar whole genome microarrays and relative RT PCR, we found that similar to ET304, the majority of the family members display root-predominant expression patterns. Further comparative analysis of poplar, Arabidopsis, and rice genomes confirmed that ET304-like families of putative AT-hook transcription factors are phylogenetically conserved among all three genomes. The pET304 promoter, and potentially the promoters of other root-predominant genes of ET304-like families, is excellent candidates for the utilization in tree carbon sequestration research and biotechnology.

- The other tested promoters included: 1) pCgMT1 - root-predominant promoter from a tropical tree (Casuarina glauca) and 2) pAtPIN2 - promoter from Arabidopsis root specific PIN2 gene. The $p C g M T 1$ promoter showed high levels of activity in roots of multiple poplar transgenic lines; however, its expression was not limited to root tissues as $p C g M T 1$-driven GUS expression was frequently observed in leaves and other aerial parts. The high activity of the pCgMT1 promoter makes it a good candidate for general use in tree biotechnology although a background expression of $p C g M T$ in aerial parts has limited the utility of this promoter in carbon sequestration by roots.

- The Arabidopsis promoter from the PIN2 gene (encoding an auxin carrier protein) was active in Populus root tissues and cell files involved in basipetal auxin transport. Therefore, pAtPIN2 was identified as a good candidate for the utilization in tree carbon sequestration research and biotechnology.

2.1.3. Strong constitutive expression or silencing of target genes may interfere with the recovery of viable transgenic plants. To overcome these limitations several chemically inducible systems have been recently developed. To our knowledge, none of these systems were successfully tested 
in woody plants. To evaluate the efficiency of two chemically regulated promoter systems, alcohol- and estrogen-inducible, OSU tested them in multiple poplar transgenics.

- We investigated the function of an alcohol-responsive gene induction system in transgenic Populus using multiple independent transformation events in two different genetic backgrounds. Upon induction, the activity of GUS enzymes in poplar tissues was measured using fluorometry. The optimal inducer concentration and the duration of induction period were determined in dose response and time course experiments, respectively.

- We demonstrated that among the tested chemical inducers, ethanol was the most effective activator when concentrations were at or below $2 \%$. Acetaldehyde at higher concentrations was limited by its toxicity to poplar plants. In contrast, up to 8\% ethanol had no apparent toxic effects to plants both in tissue culture and in greenhouse conditions. The alcA promoter system was sensitive to the induction by ethanol in concentrations as low as $2 \%$.

- A long-term (up to 30 days) continuous induction showed significant increase of GUS levels. Vapor treatment was an effective induction procedure resulting in high levels of GUS activity in leaves.

- The induction by ethanol was more efficient in plant growth in tissue culture as compared to greenhouse conditions. No significant GUS activity was detected in roots of greenhouseinduced transgenic trees.

- The alcohol-inducible system was functional in transgenic poplar and allowed temporal control of gene expression (Filichkin et al., 2006b).

- The alcohol-inducible "gene switch" was proposed for utilizations in studies of developmental genes improving transformation efficiency in poplar and other plants (Arias et al., 2006).

- Two estrogen-inducible systems were evaluated in transgenic Populus. Neither of the systems functioned reliably in tissue culture conditions.

\subsubsection{Construction of RNAi vectors.}

To facilitate high throughput gene silencing, we designed GATEWAY-compatible plant binary vectors with similar backbones in which dsRNAs with either homologous (direct) or heterologous (transitive) inverted repeats and driven by identical constitutive promoters. These vectors allowed direct comparison of silencing efficiency for both types of RNAi. To evaluate the suppression effects of direct and transitive RNA interference methods in Populus, a set of genes was targeted for post transcriptional silencing in the model Arabidopsis system. This set included:

1. floral meristem identity gene APETALA 1 (AP1);

2. auxin response factor ETTIN;

3. TRANSPARENTTESTAGLABRA1 (TTG1) gene encoding transcriptional factor of WD40 family (TTG1 regulates trichome differentiation/anthocyanin biosynthesis); and

4. auxin efflux carrier, PIN-FORMED2 (PIN2) required for gravitropic root growth.

- More than 220 transgenic lines of the $1^{\text {st }}, 2^{\text {nd }}$ and $3^{\text {rd }}$ generations were analyzed for RNAi suppression phenotypes of the targeted genes listed above.

- Both direct (self-complementary intron-spliced inverted repeat of the target sequence, hIR) and transitive (sequence fragment of the target gene cloned adjacent to heterologous IR) AP1 RNAi constructs induced silencing of selected target genes. 
- Both direct IR and transitive AP1 RNAi constructs produced highly visible phenotypes consistent with observations reported for ap1 loss of function mutants. Both direct IR and transitive AP1 RNAi constructs showed high penetrance and stable inheritance in T2 progeny. Direct IR AP1 RNAi constructs have had a higher proportion of strong, and a lower proportion of weak phenotypes when compared to transitive RNAi constructs. Strong AP1 RNAi phenotypes resulted in complete or partial plant sterility. The depletion of AP1 mRNA levels were confirmed by a quantitative reverse transcription polymerase chain reaction (qRT-PCR). Expression profiling of a number of genes, including a cluster of floral homeotic genes in the AP1 pathway, was affected by both transitive and direct IR RNAi. Changes observed in expression of several floral developmental genes were corroborated by qRTPCR. Thus, AP1 RNAi suppression demonstrated to be an effective tool for regulation of plant sterility in a model system with great potential for applications in poplar biotechnology.

- RNAi suppression of the ETTIN target gene resulted in abnormal development and reduced or increased number of floral organs. An overall penetrance of ETTIN RNAi suppression was relatively low. In contrast to $A P 1$, the RNAi silencing of ETTIN had no or little effect on plant sterility.

- $\quad$ TTG1 RNAi constructs displayed moderate suppression of trichome development with a low frequency of transgenics with trichomless leaves. Further evaluation of TTG1 RNAi effects on seed and root hair development is in progress.

- No highly visible agravitropic root phenotypes were observed for RNAi suppression of PIN2 target gene using both direct and transitive constructs. The analysis of PIN2 mRNA synthesis showed that approximately 50\% T1 transformants had depleted levels of mRNA.

- We further evaluated efficiency and potential off-target effects of AP1 gene silencing by transitive and direct IR constructs using genome-scale microarrays and quantitative RT PCR. We report broadly similar levels of gene silencing, and no evidence of significant offtargeting, caused by either RNAi method.

- Overall, the direct IR vector had a higher proportion of events with strongly manifested silencing phenotypes while the recombination-based vector for transitive RNAi had advantages of rapid sequence-independent cloning and targeting of multiple genes useful in high throughput poplar functional genomics. A combination of direct IR and transitive vectors provides a set of effective tools for applications in poplar functional genomics and the discovery of novel genes for modification of carbon sequestration.

2.2. A total of 108 constructs supplied by ORNL and UF and several built at OSU, were used to generate transgenic Populus plants. The major types of vectors utilized for poplar transformation included cDNA over-expression and RNA interference (RNAi) vectors (for both RNAi-direct and RNAi-transitive gene silencing). Detailed backbone description, vector maps and sequences are available via the ORNL Web site at http://www.esd.ornl.gov/PGG/cap/belowground_poplar_project_vectors.htm.

The production of a panel of Populus transgenics required Argobacterium co-cultivation of 124,406 explants. A total of 1,881 Populus and approximately 320 of Arabidopsis independent transgenic events were produced and verified by PCR. OSU transformation efforts for poplar are summarized in Table 1. Specific details and timelines in OSU production of transgenic trees are 
shared with project collaborators and can be accessed at http://www.esd.ornl.gov/PGG/cap/project_internal.htm. 


\section{CONFERENCE PAPERS/PROCEEDINGS AND JOURNAL ARTICLES}

\section{Presentations at professional meetings.}

S. A. Filichkin. Alcohol-Inducible Gene Expression In Transgenic Poplar. Plant \& Animal Genomes XIII Conference; San Diego, January 15-19, 2005. P519 (http://www.intlpag.org/13/abstracts/PAG13_P519.html).

S. A. Filichkin. Directed functional genomics. Tree Biosafety and Genomics Research Cooperative Annual Meeting. Oregon State University, November 2004.

\section{Publications}

Filichkin, S.A., Q. Wu, V.B. Busov, R. Meilan, C. Lanz-Garcia, C. Ma, P. Dharmawardhana, A.M. Brunner, and S.H. Strauss. 2006a. Enhancer trapping in woody plants: Isolation of the ET304 gene encoding a putative AT-hook motif transcription factor and characterization of the expression patterns conferred by its promoter in transgenic Populus and Arabidopsis . Plant Sci. 171(2): 206-216.

Filichkin, S.A., Meilan, R., Busov, V.B., Ma, C., Brunner, A.M. and Strauss, S.H. 2006b. Alcohol-inducible gene expression in transgenic Populus. Plant Cell Rep. 25(7): 660667.

Arias R.S., Filichkin S.A., Strauss S.H. 2006. Divide and conquer: development and cell cycle genes in plant transformation. Trends Biotechnol. 24(6): 267-273.

Busov V.B., Brunner A.M., Meilan R., Filichkin S., Ganio L., Gandhi S., Strauss S.H. 2005. Genetic transformation: a powerful tool for dissection of adaptive traits in trees. New Phytol. 167: 9-18.

S. H. Strauss, A. Brunner, S. A. Filichkin, S. Gandhi, E. Jaeger, J. Li and C. Ma. 2004. Improvement of transformation tools for directed functional genomics. Tree Biosafety and Genomics Research Cooperative. Annual Report. pp. 24- 26.

C. Ma, S. H. Strauss, and R. Meilan. 2004. Agrobacterium-mediated transformation of the genome-sequenced poplar clone, 'Nisqually-1' (Populus trichocarpa). Plant Mol. Biol. Rep., 22, 1-9.

Meilan, R., M. Sabatti, C. Ma., E. Kuzminsky. 2004. An early-flowering genotype of Populus. J. Plant Biol., 47, 52-56.

Meilan, R. and C. Ma. 2005. Populus. In: Agrobacterium Protocols, Methods in Molecular Biology, vol. 44. Ed. K. Wang, Humana Press.

Filichkin, S.A., DiFazio, S.P., Brunner, A.M., Davis, J.M., Kalluri, U.C., Yang, Z.K., R.S., Etherington, E., Tuskan, G.A., Arias, Strauss, S.H. Efficiency of gene silencing in 
Arabidopsis : Direct inverted repeats versus transitive RNAi vectors. Manuscript submitted. 


\begin{tabular}{|c|c|c|c|c|}
\hline $\begin{array}{l}\text { Group of Constructs } \\
\text { (Institution) }\end{array}$ & $\begin{array}{l}\text { Number of } \\
\text { Constructs }\end{array}$ & $\begin{array}{l}\text { Explants } \\
\text { Co- }\end{array}$ & $\begin{array}{l}\text { PCR } \\
\text { verified }\end{array}$ & $\begin{array}{l}\text { Status Of Product } \\
\text { Delivery }\end{array}$ \\
\hline Invertases (UF) & 11 & 14,352 & 262 & $\begin{array}{l}\text { Transgenic lines } \\
\text { delivered to UF }\end{array}$ \\
\hline $\begin{array}{l}\text { Tester Lines (OSU \& } \\
\text { UF) }\end{array}$ & 4 & 6,925 & 89 & $\begin{array}{l}\text { Transgenic lines } \\
\text { delivered to UF, } \\
\text { tested at OSU }\end{array}$ \\
\hline Vector Controls (ORNL) & 3 & 2,294 & 17 & $\begin{array}{l}\text { Accomplished, } \\
\text { transgenic lines } \\
\text { delivered to ORNL }\end{array}$ \\
\hline $\begin{array}{l}\text { Estrogen Inducible } \\
\text { (OSU) }\end{array}$ & 2 & 2,606 & 71 & $\begin{array}{l}\text { Testing } \\
\text { accomplished }\end{array}$ \\
\hline $\begin{array}{l}\text { Alcohol Inducible } \\
\text { System (OSU) }\end{array}$ & 1 & 1,828 & 33 & $\begin{array}{l}\text { Testing } \\
\text { accomplished, } \\
\text { manuscript } \\
\text { published }\end{array}$ \\
\hline $\begin{array}{l}\text { Root Predominant } \\
\text { Promoters (OSU) }\end{array}$ & 7 & 4,922 & 132 & $\begin{array}{l}\text { Testing } \\
\text { accomplished, } \\
\text { manuscript } \\
\text { published }\end{array}$ \\
\hline $\begin{array}{l}\text { Yeast Invertase } \\
\text { Overexpression (UF) }\end{array}$ & 3 & 2,837 & 80 & $\begin{array}{l}\text { Accomplished, } \\
\text { transgenic lines } \\
\text { delivered to UF }\end{array}$ \\
\hline $\begin{array}{l}\text { Response Regulators } \\
\text { (UF) }\end{array}$ & 4 & 7,218 & 87 & $\begin{array}{l}\text { Accomplished, } \\
\text { transgenic lines } \\
\text { delivered to UF }\end{array}$ \\
\hline $\begin{array}{l}\text { TRANSPARENT TESTA } \\
\text { GLABRA-like loci } \\
\text { RNAi (UF) }\end{array}$ & 12 & 15,227 & 273 & $\begin{array}{l}\text { Accomplished, } \\
\text { transgenic lines } \\
\text { delivered to UF }\end{array}$ \\
\hline Auxin/IAAs (ORNL) & 26 & 29,577 & 625 & $\begin{array}{l}\text { Accomplished, } \\
\text { transgenic lines } \\
\text { delivered to ORNL }\end{array}$ \\
\hline $\begin{array}{l}\text { Auxin Response Factors } \\
\text { (ORNL) }\end{array}$ & 16 & 17,217 & 150 & $\begin{array}{l}\text { Transgenic lines } \\
\text { are currently being } \\
\text { delivered to ORNL }\end{array}$ \\
\hline $\begin{array}{l}\text { Cytokinin Response } \\
\text { Regulators (UF) }\end{array}$ & 19 & 19,403 & 62 & $\begin{array}{l}\text { PCR testing in } \\
\text { progress }\end{array}$ \\
\hline
\end{tabular}

